\title{
AKADEMIE EN POLITIEK 1
}

\author{
A.A. van Niekerk \\ Departement Filosofie \\ Universiteit van Stellenbosch \\ STELLENBOSCH
}

\begin{abstract}
The purpose of this article is to develop a view conceming the relationship between acadeny and politics, particularly by saking into accoum the way in which developments in the institutionalised practice of the university are relevant or irrelevant for our understanding of the idea of the university. The specific question which the author addresses is: what are the peculiar characteristics and mutual relcvance of the two human activities which we respectively call academy and politics? Firstly, he discusses views in tems of which academy and politics are radically separated and in lerms of which arguments for the alleged political "neutrality" of the university are developed. Secondly, he identifies three cultural and philosophic developments which, since the advent of modemity, have challenged the viability of such separation. Thirdly, he develops a position which mediates between the extremes of an ahistorical academic elitism and a historistic ideologising of university and science.
\end{abstract}

\section{AKADEMIE EN POLITIEK}

'n Universiteit is een van die beste voorbeelde van 'n gë̈ntitusionalisecrde idee, dit is 'n gebruik of 'n lewenswyse waardeur die samelewing 'n legitimerende sanksie verleen aan, geleenthede skep en bronne voorsien vir die praktiese vergestalting van die soort leefwyse of handelingspatroon wat deur die betrokke idee voorgeskryf word. 'n Universiteit is die geïnstitusionaliseerde vergestalting van die idee dat, soos Karl Jaspers (1960:19,21) dit stel, "... it is a human right that man must be allowed somewhere to pursue truth unconditionally for its own sake ... The university, then, is an institution uniting people professionally dedicated to the quest and transmission of truth in scientific terms".

Dit is 'n lastige vraag of die idee die instelling logies en chronologies voorafgaan, en of wat ons in die praktyk kan agterkom omtrent die instelling, altyd toetsbaar is aan die voorskrifte van die "oorspronklike" idee waaruit die instelling voortgespruit het. In die geskiedenis van die besinning oor die verhouding tussen akademie en politiek is daar

\footnotetext{
${ }^{1}$ Oorspronklik aangebied as decl van die Stokerlesings, gereël deur die Departement Filosofic van die PU vir (CHO op 2 Augustus 1990.
} 
byvoorbeeld 'n baie sterk tradisie wat die politieke invloed op en invloed van, sowel as die politieke relevansie van universiteite sterk opponeer omdat dit kwansuis in stryd is met die oer-idee wat ten grondslag van die universiteit as instelling lê. Die veronderstelling van sodanige protes is dat die idee die instelling nie alleen chronologies nie, maar ook logies voorafgaan en daarom in sy onveranderlike gelding normatief bly funksioneer vir die de facto-beoefening van die akademie. ${ }^{2}$

So ' $\mathrm{n}$ veronderstelling is myns insiens problematies, sonder dat ek daarmee wil beweer dat die idee van die universiteit inhoudelik uitgelewer is aan die voorskrifte van 'n histories bepaalde praktyk. Wat ek betwis, is dat die idee van die universiteit ' $n$ tydlose, universele betekenis het wat self onberoerd bly deur die prosesse van snelle verandering waaraan sowel die instelling van die universiteit as die samelewing waarin hy hom onvermydelik bevind, blootgestel is. Die verband tussen teorie en praktyk verloop nie slegs in een rigting nie, maar die twee beïnvloed mekaar wedersyds.

Die doel van hierdie artikel is om 'n perspektief te ontwikkel op die verhouding tussen akademie en politiek met inagneming van die wyse waarop ontwikkelinge in die geïnstitusionaliseerde praktyk relevant of irrelevant is vir die verstaan van die idee van die universiteit. Die meer spesifieke vraag wat my interesseer, is wat die eiesoortige aard, maar ook wedersydse relevansie van die twee soorte menslike bedrywighede is (selfs lewenswyses?) wat ons onderskeidelik "akademie" en "politiek" noem. Het ons hier te make met "soewereiniteite in eie kring", met aparte en totaal eiesoortige aktiwiteite wat in isolasie van mekaar verstaan en beoefen moet word en wat elk 'n ononderhandelbare institusionele outonomie het, of met benaderingswyses tot die werklikheid wat ooreenkomste vertoon en daarom konstruktief op mekaar kan inspeel? Dit is vanuit ' $n$ interesse in hierdie problematiek dat vrae rondom die neutraliteit en politieke verantwoordelikheid van die universiteit dan uiteindelik aan die orde kom.

Ten einde hierdie probleem te omlyn, stel ek in die eerste plek in breë trekke die standpunt aan die orde waarvolgens akademie en politiek radikaal van mekaar geskei word, en in terme waarvan die vermeende politieke "neutraliteit" van die universiteit beredeneer word. Tweedens wys ek op enkele filosofiese sowel as kulturele verskuiwings wat, sedert die aanbreek van die moderne tyd, die houdbaarheid van so 'n skeiding toenemend in gedrang bring. Ten slotte ontwikkel ek 'n perspektief op hoe

\footnotetext{
2 Wanneer ek die begrip akademie gebruik, bepaal ck my by dic praktyke van kennisverwerwing en -mededeling soos beocfen word aan universiteite. Dit is seker moontlik om die begrip ' ruimer toepassingsveld te gee, mar dan moct ck my waag aan die beoordeling van vergelykbare praktyke aan (onder andere) opvoedkundige instellings (soos tegnikons, kolleges en skole) waarmee ck nic voldoende vertroud is nie.
} 
bemiddel kan word tussen die uiterstes van 'n ahistoriese akademiese elitisme en 'n historistiese verideologisering van universiteit en wetenskap. Dit doen ek deur 'n beskouing te ontwikkel van die verhouding tussen akademie en politiek waarin die politieke verantwoordelikheid van die universiteit erken word sonder om op 'n manier verstaan te word wat die onvervreembare akademiese vryheid en outonomie van die universiteit in die gedrang bring.

\section{DIE UNIVERSITEIT AS IVOORTORING}

Dat akademie en politiek twee eiesoortige bestaansmodi verteenwoordig wat slegs by risiko van wedersydse benadeling met mekaar in verband gestel kan word, is 'n standpunt met ' $n$ breë ondersteuning in die literatuur. (Vgl. vir beredenerings hiervan Weber, 1973; Minogue, 1973:73-102; Moberly, 1949: Simon, 1972 en Searle, 1972.) Die argumente in hierdie verband is uiteenlopend van aard, maar ek wil net wys op drie oorwegings wat in hierdie verband veral opval.

Die eerste oorweging hang saam met 'n besonder negatiewe beoordeling van die wyse waarop die akademiese kennistrewe, wanneer dit inspeel op die de facto-inrigting en bedryf van die politieke lewe, laasgenoemde beïnvloed. Die argument in hierdie verband herlei die verskille tussen ons verhouding tot en omgang met die werklikheid in akademie en politiek tot die klassieke onderskeiding in die Griekse filosofie tussen episteme (seker wete) en doksa (mening/opinie). Die strewe na episteme word op gang gebring en gestuur deur die regulatiewe idee van waarheid (aletheia) as finale epistemologiese norm. Dit is algemeen bekend dat die onderskeiding tussen episteme en doksa, soos verduidelik in Plato se klassieke grotbeeld, die aangrypingspunt vorm van die Griekse Aufklärung, en daarom van die ganse filosofies-intellektuele en uiteindelik ook akademies-wetenskaplike tradisie van die Westerse kultuur.

Dit is egter 'n ope vraag of die strewe na episteme, na teoreties gekonsipieerde en rasioneel verantwoordbare kennis - die strewe wat sedert die Middeleeue institusionele beslag gekry het in die universiteit - van veel belang is vir die inrigting van die politieke lewe in die samelewing. 'n Denker soos Hannah Arendt betwis nie alleen die aanspraak dat die menslike kennisstrewe van enige belang vir die politiek is nie, maar meen selfs dat die waarheidstrewe van die eerste filosowe die doodsklok gelui het vir die lewenskragtige demokrasie van die Griekse polis, want in die politiek gaan dit volgens Arendt (1961: 241 e.v.) nie om waarheid nie, maar juis om die onherleibare variasie en pluraliteit van opinies. 'n Demokratiese politieke interaksie is per definisie nie gerig op die verwerwing van 'n seker wete nie, maar op die vorming van opinies deur die blootstelling van opinies aan ander opinies in 'n openbare debat. 
There is no test for the adequacy of an opinion, no authority for judging it, other than the force of the better public argument. The formation of opinions, therefore, requires a political community of equals, the imagination to represent other viewpoints, and the courage to submit opinions to public exposure and test. While we seck agreement in opinion, it is not a defect or flaw in opinion formation if we fail to reach agreement - for the variability of opinions is an expression of ineradicable human plurality (Bernstein, 1986:228).

Die nuwe gesag waarmee waarheid sedert Plato beklee is as finale arbiter in situasies van meningsverskil, het volgens Arendt 'n deurslaggewende bydrae daartoe gelewer om die kort intermezzo van demokrasie in die Griekse polis voortydig te laat eindig. Waarheid in die politiek het geblyk slegs 'n magsmiddel in die hande van outoritêre tiranne te wees. Hoewel Arendt haar nie eksplisiet uitgelaat het oor die verhouding tussen universiteit en politiek nie, is die implikasie van haar standpunt duidelik: hou politiek en akademie sover moontlik uit mekaar, want die strewe na waarheid blyk in die politiek slegs 'n handige verskoning vir die uitdowing van kritiek en van die plig tot 'n openbare verantwoording van standpunte en optredes te wees.

'n Tweede oorweging ter ondersteuning van die skeiding van akademie en politiek wys op die verskillende interesses waardeur die kontemplatiewe refleksie van akademiese ondersoek en die noodsaak tot praktiese optrede van die politiek onderskeidelik gestuur word. Die akademie strewe na waarheid; die politiek na praktiese nuttigheid of effektiwiteit; en die twee val nie noodwendig saam nie. Apologete van hierdie standpunt ontken nie die opsigtelike feit dat akademies verworwe kennis dikwels 'n opvallende en besonder nuttige praktiese toepasbaarheid het nie. Die punt is egter dat praktiese toepasbaarheid hoegenaamd nie 'n deurslaggewende kriterium is in die bedryf van die akademiese lewe nie.

'n Mens sou byvoorbeeld in hierdie verband daarop kon wys dat daar 'n groot aantal valse oortuigings is wat net so nuttig is soos ware oortuigings. Geloofsgeneeshere genees mense van siektes waarvan hulle normaalweg baie min verstaan. 'n Groot aantal kure vir psigiatriese siektes word voorgeskryf en uitgevoer deur psigiaters wat beskouinge oor die menslike psige huldig wat wedersyds kontradiktories is. Hierteenoor sou 'n mens weliswaar kon reageer dat die nuttigheid van valse oortuigings uiters beperk is; die moderne sterrekunde mag nou wel nie veel nuttiger as die Ptolemeïese sterrekunde vir die doeleindes van beperkte navigasie op die Middelandse see wees nie, maar dit kan tog nog oneindig meer effekte behaal as sy primitiewe konkurrente. Om die uniekheid en onherleibaarheid van 'n akademiese benadering tot probleme aan te toon, is dit vir apologete van hierdie soort standpunt daarom ook belangrik om 
te argumenteer dat daar elemente van valsheid in die praktiese politieke lewe is wat noodsaaklik en onverwyderbaar vir die voortsetting van die praktiese lewe van die politiek is - dit wat Kenneth Minogue (1973) "necessary useful errors" noem.

In sy boek oor die begrip universiteit (Minogue 1973) gee hy die volgende voorbeeld van so 'n "useful error": "Politicians, spies and fugitives ... usually assume that no one is to be trusted, and this is usually false. But the true belief (that some people are not to be trusted) [d.i. dus ook dat sommige mense wel vertrou kan word - AAvN] would be of little use. Hence there is at least one kind of systematic error in some practical activities - that which comes from erring on the safe side" (Minogue, 1973:85). Waarheid - die enigste maatstaf wat relevant is vir die akademie - val dus nie noodwendig saam met die oorwegings van nuttigheid en effektiwiteit wat die haalbaarheid van oortuigings en optredes in die politieke lewe bepaal nie.

Die derde oorweging in die lig waarvan die eiesoortigheid en daarom skeibaarheid van akademie en politiek beredeneer word, berus op die opsigtelike waarneming dat niemand aan 'n universiteit tot 'n konklusie moet kom waarop 'n besluit gebaseer moet word nie. Akademici kan hulself altyd die luukse veroorloof dat hul konklusie alleen bepaal hoef te word deur die beskikbare getuienis; juis daarom spandeer hulle dikwels baie tyd om te verduidelik waarom geen verdere substansiële gevolgtrekkings oor die moontlike oplossing van 'n bepaalde probleem moontlik is nie! En selfs wanneer hulle by geleentheid tot 'n konklusie kom, vind die meeste akademici, soms ook tot eie ontnugtering, uit dat daardie konklusie nie 'n onherroeplike tree vooruit op die vermeende goue weg van kennisprogressie is nie, maar dat dit slegs met huiwering balanseer op 'n onstabiele korpus van getuienis wat jonger akademici altyd geneig is om te hersien. Om Minogue weer aan te haal: "In the academic world, conclusions simmer together with the evidence, and there is no point at which they can ever be detached from it" (1973:86). In die prakties-politieke wêreld, daarenteen, is konklusies meermale geneig om die getuienis wat hulle ondersteun vir ' $n$ lang tyd te oorleef, want in daardie wêreld is die neem van besluite nie alleen onvermydelik nie, maar meesal ook dringend. Sulke besluite moet gewoonlik ook geneem word op grond van wat, in akademiese terme, onvoldoende gronde of getuienis is. Daar kleef noodwendig aan die besluite van die prakties-politieke lewe 'n element van improvisasie wat sodanige besluite onderhewig maak aan foutering. Een van die belangrikste prestasies van die Westerse kultuur is volgens hierdie argument dan juis die feit dat dit instellings soos universiteite tot stand gebring het waarin lewenskondisies kunsmatig geskep is waarin hierdie druk om tot die beste beskikbare besluit te kom, berekend geneutraliseer is. Die onvermoë om te onderskei tussen akademie en politiek, en 'n aandrang op die politieke betrokkenheid en relevansie van universiteite en akademiese werk, behels 
daarom volgens apologete van hierdie standpunt 'n bedreiging vir die wese van dit wat die universiteit as instelling sy unieke identiteit in ons kultuur laat verwerf het. Die blurring van die onderskeiding tussen akademie en politiek hou dus, volgens hierdie beskouing, nie alleen 'n bedreiging vir die behoud van die eiendomlike karakter van die politiek in nie, soos ons gesien het by die eerste oorweging, maar ook en veral vir die behoud van die eiendomlike karakter van die universiteit.

\section{VERSKUIWINGS IN FILOSOFIE EN KULTUUR}

Daar sou verskeie oorwegings aangevoer kon word waarom die dualisme van akademie en politiek onaanvaarbaar is. Soos in die vooruitsig gestel aan die begin, lê die swaartepunt van my beswaar daarteen in die feit dat hierdie dualisme uitgaan van die veronderstelling dat die idee van die universiteit volledig normatief funksioneer met betrekking tot die ervaring en praktyk wat die historiese institusionalisering van die idee van die universiteit begelei het, en dat die idee self bygevolg nie onderworpe is aan verandering en aanpassing, soos geïnformeer deur genoemde ervaring en praktyk nie. Dit is byvoorbeeld algemeen bekend dat universiteite hul oorspronklike institusionele beslag gekry het in die monnike-kultuur van die Middeleeue. En hoewel dit sekerlik so is dat elemente van die Middeleeuse universiteitswese tot vandag toe 'n sekere geldigheid behou vir die idee van die universiteit, toon selfs die oppervlakkigste vergelykings onomwonde aan dat moderne universiteite radikaal andersoortige instellings is as hul Middeleeuse voorlopers. Die moderne universiteit, en met name die soort kennis- en rasionaliteitsteorie in terme waarvan die moderne universiteit sy akademiese taak verrig, is veeleer 'n produk van die Verligting as van die Middeleeue. Die brandpunt van hierdie teorie is, soos James Moulder (1977:251) dit stel, " ...that knowledge is more likely to be advanced through free inquiry than through collective endorsement or rejection. More specifically, hypotheses can only be validated as knowledge - as opposed to dogma or official party policy - by being subjected to the tests of free inquiry". Laasgenoemde verteenwoordig 'n totaal ander wêreld as dié van die Middeleeuse universiteit waar die proses van die verwerwing, sistematisering en oordrag van kennis volledig in diens was van die verstaan en verdediging van die gesaghebbende kerklike dogmas. Die moderne universiteit, sou 'n mens kon beweer, dank in 'n sekere sin sy ontstaan aan 'n direkte reaksie op die kenniskultuur van die Middeleeue. John Searle (1971:171) merk in hierdie verband op: "[At the modern university] no proposition is so sacred as to be immune from these tests [of critical inquiry]; every proposition derives what validity it has through surviving these tests". Met hierdie erkenning gee Searle by implikasie toe wat myns insiens nie genoegsaam 
verreken word in sy andersins waardevolle bydraes oor die idee van die universiteit nie: dat die idee self deurlopend onderworpe bly aan historiese verandering, en dat hierdie veranderinge onherroeplik saamhang met die de facto-ervaring en praktyk van die universiteit as sosiaal gelokaliseerde, historiese instelling.

Ek wys vervolgens baie kortliks op drie ontwikkelinge wat die dualisme van die vorige paragraaf problematiseer. Die eerste twee is kultuurhistoriese tendense wat sedert die aanvang van die moderne tyd met ons is. Die laaste een is 'n spesifiek (wetenskaps-) filosofiese verskuiwing wat eers na behore sy beslag gekry het in die twintigste eeu.

Die oudste van genoemde drie ontwikkelinge is die opkoms en groeiende impak van 'n wetenskapskultuur waarin die ideaal van deug as doel van die kenproses vervang word deur die ideaal van mag ${ }^{3}$. Sedert die aanvang van die moderne tyd is die akademiese bedryf van die universiteit lank nie meer uitsluitlik daarop gemik om deug te bevorder nie, dit wil sê om mense geestelik en intellektueel so te vorm dat hulle oor sowel die rigtingbesef as die kritiese insig en die keusebevoegdheid beskik om hulself op 'n geslaagde wyse in die werklikheid te oriënteer nie. Aan die moderne universiteit gaan dit ook en toenemend om wetenskapsbeoefening en wetenskapsbeoefening dien nie alleen'n kennis- of waarheidstrewe nie, maar ook 'n magstrewe ${ }^{4}$. Sedert die aanvang van die moderne tyd word die sin van wetenskapsbeoefening toenemend gesoek in die intellektuele beheersing 5 van ervaringsverskynsels en in die praktiese nut wat so 'n beheersing vir die mens kan hê in sy onderwerping en kontrolering van die kragte wat in sy natuurlike en sosiale omgewing werksaam is. "So", skryf Rossouw, "het 'n nuwe wetenskapskultuur ontstaan wat rasionele en sistematiese kennis nie stel in diens van die menslike ethos nie, maar eerder in diens van die menslike techné; nie in diens van die mens se oriëntasievermoë nie, maar eerder in diens van sy tegniese vernuf en vaardigheid om nuwe dinge en toestande te produseer deur die beheersing en bewerking van gegewe materiaal" (1986:58).

Dit alles het verreikende gevolge vir die aard en selfverstaan van die moderne universiteit gehad, en dit problematiseer toenemend die idee dat die universiteit

\footnotetext{
${ }^{3}$ Die mees bevredigende bespreking van hicrdie insig is die van Rossouw (1986).

${ }^{4}$ Vergelyk die bekende slagspreuk van Francis Bacon: "Kennis is mag", asook René Descartes se pleidooi vir 'n wetenskap wat ons "meesters en besitters van die natuur" sal maak.

5 Hicrmee word bedoel dic opspoor van die wetmatighede wat die gedrag van ervaringsverskynscls bepaal, ten cinde hierdic gedragswyses te kan voorspel en sodoende te kan inspan met dic oog op die vervulling van praktiese bestaansbehoeftes. Vir 'n verhelderende bespreking van dic verklaringslogika van dic moderne natuurwetenskappe waarop hierdie magstrewe berus, vergelyk Doyal \& Harris (1986:27-51).
} 
neutraal staan teenoor die heersende politiek. Dit gaan immers juis in die politiek om magsverwerwing en magsbehoud, en dit was daarom nie lank voordat die politieke maghebbers van state wat universiteite huisves onder die indruk gekom het van die magspotensiaal wat wetenskaplike kennis bied, via die toepassing daarvan in tegnieke en tegnologieë van groeiende sofistikasie. Die moderne universiteit het hom dit boonop redelik moeiteloos laat welgeval dat die staat en privaatmaatskappye sy vernaamste bron van finansiering word, en dat die eis van sogenaamde "praktiese relevansie" as gevolg daarvan toenemend aan sy navorsingsbedrywighede gestel word 'n eis wat, volgens meer radikale teoretici, op niks anders neerkom nie as die diensbaarmaking van die universiteit aan die strukture van dominasie en verdrukking van 'n bepaalde polities-ekonomiese bestel nie 6 .

'n Tweede kulturele ontwikkeling, wat histories eers later op die toneel verskyn het, was die opkoms van die moderne mens se historiese bewussyn, dit is die besef van die radikale onderworpenheid van alle kennis en insig aan die onvermydelike proses van historiese verandering, en bygevolg van die relativering van die skynbaar universele gelding waarmee norme, waardes, oortuigings en praktyke tradisioneel gehuldig en verdedig is. Sonder om in meer besonderhede hierop te kan ingaan, wys ek slegs op een implikasie van die invloed van die moderne mens se historiese bewussyn vir die debat oor die verhouding tussen akademie en politiek: die idee, naamlik, dat alle prosesse van (ook akademies-wetenskaplike) kennisverwerwing die funksie is van sosiaal-historiese kondisies wat in direkte verband staan met die behoeftes, voorkeure en selfs vooroordele van bepaalde historiese omstandighede en gemeenskappe. Hierdie idee word op die mees pregnante wyse verwoord in die bekende slagspreuk van Karl Marx: "Life is not determined by consciousness, but consciousness is determined by life" (Marx \& Engels, 1970:47). Toegepas op ons probleem, beteken dit dat die akademikus se keuse van probleme, metodes van ondersoek en seleksie van ondersteunende of weerleggende getuienismateriaal 'n funksie is van sy sosiaalhistoriese, politieke en ekonomiese leefomstandighede. 'n Skeiding van akademie en politiek is daarom op sy beste naïef en op sy slegste 'n blufspel waarin die dienstigheid van universiteit en wetenskap aan 'n bepaalde politieke en ekonomiese praktyk berekend verdoesel word?

\footnotetext{
${ }^{6}$ Vir 'n mecr uitvoerige beredenering van hierdie standpunt, waarop ck hier nie verder kan ingaan nic, vergclyk Althusser (1972), Marin (1975) en Musgrave (1973.)

${ }^{7}$ Marxistiese standpunte oor die verhouding tussen wetenskap en politiek is natuurlik nic al voorbeeld van die deurwerking van die historiese bewussyn in hierdie verband nie. 'n Mens sou ewe goed kon verwys na die strukt uralistiese analises van die verwantskap tussen kennis en mas by Foucault (vgl. Foucault 1980:109-133) of dic prysgawe van die ideale van waarheid objektiwiteit en rasionaliteit ten gunste van solidaritcit met 'n gemeenskap in die denke van dic sogenaamde "Post-moderniste" (vergelyk bv. Rorty, 1985:3-19). Die verskil tussen dic Post-
} 
Die derde en laaste ontwikkeling wat krities inspeel op die idee van die skeibaarheid van akademie en politiek is die verskuiwinge wat die filosofiese wetenskapsbeeld gedurende die loop van die twintigste eeu ondergaan het ${ }^{8}$. Hierdie verskuiwinge hang saam met sowel die geleidelike deurwerking van die insigte van die sogenaamde "kennis-sosiologie"9 as met 'n tendens in die wetenskapsfilosofie en -metodologie om minder abstrak en voorskriftelik te praat oor "die wetenskaplike metode" en om veel meer ag te slaan op die de facto-bedryf van die wetenskappe, soos dit verwikkel is met die totaliteit van die menslike lewe, in die daaglikse (en dus veral universitêre) praktyk. (Vergelyk in hierdie verband veral die nou reeds epogmakende bydraes van Thomas Kuhn $(1962,1970)$ en Lakatos (1970)).

Omtrent hierdie vermelde verskuiwinge wys ek in die algemeen slegs daarop dat die insig geleidelik begin groei dat die wyse waarop akademies-wetenskaplike kennis verwerf word, nie soseer die vrug is van 'n universeel geldige en logies formaliseerbare metode 10 wat uniform op alle kennisgebiede toegepas kan word nie, maar dat die wetenskap 'n menslike, sosiale en histories-bepaalde aktiwiteit is. "Science", skryf Stephen Toulmin (1961:99), "is not an intellectual computing machine; it is a slice of life". Daarom kan dit verwag word dat die beoefening van die wetenskap ook die tipiese kenmerke van historiese, sosiale menslike verskynsels sal vertoon, byvoorbeeld die rol van gesag en tradisie, solidariteit met 'n groep, vertroue en persoonlike verbintenisse, variasies van individuele oordeel, konsensus wat op oorreding berus; maar ook verlies aan vertroue, gemeenskapskrisisse, polarisasie, kommunikasiegapings en onderlinge spanning.

Die besef van die wyse waarop al laasgenoemde faktore, wat volgens die "standaardbeeld van wetenskap" juis berekend uit die praktyk van wetenskapsbeoefening aan die

moderniste en die Marxiste is slegs dat ecrsgenoemde bereid is om dic relativerende implikasic van die historiese bewussyn ook ten opsigte van hul eie standpunte te aanvaar, terwyl die Marxiste minder ecrlik is oor dic sosiale kondisionering van hul cic maatskappy-analises, en stceds daarop aandring dat húl diskocrs 'n cksklusicwe aanspraak op rasionele status het.

8 Vir 'n meer volledige bespreking hiervan, vergelyk Rossouw (1980:1-16).

${ }^{9}$ Vir 'n bondige verduideliking van hicrdic begrip, sowel as van dic beskouinge van Karl Mannheim, wat algemeen beskou word as die vader van dic begrip kennissosiologie, vergelyk Van Nickerk (1987:25-28).

${ }^{10}$ Soos voorgestcl is deur sowel dic "standaardbecld van wetenskap" (Rossouw, 1980:2 e.v.) as dic Kriticse Rasionalisme van Karl Popper. 
universiteit uitgesluit kon word, die aktuele bedryf van die wetenskap wesenlik beïnvloed, versterk die vermoede dat die verskille tussen akademie en politiek in die verlede moontlik oorbeklemtoon is. Al die faktore wat hierbo vermeld is as invloede op die bedryf van die wetenskap, behoort immers ook wesenlik tot die sfeer van die politiek. Sonder om nou op al hierdie faktore te kan ingaan, beklemtoon ek net as 'n voorbeeld die wesenlike rol wat die uitoefening van gesonde oordeel in die praktyk van die wetenskappe speel. Hierdie aspek van wetenskapsbeoefening word treffend beredeneer in die jongste boek van die Amerikaanse wetenskapsfilosoof Harold Brown (1988) ${ }^{11}$. In aansluiting by Kuhn beklemtoon Brown dat die keuse vir 'n bepaalde "paradigma" in die praktyk van die wetenskap klaarblyklik berus op 'n besluit, gebaseer op gesonde oordeel en nie op die waardeneutrale "toepassing" van objektief geldende reëls nie. Dit is volgens Brown (en Kuhn) ook nie moontlik om sodanige keuse of besluit ooit op 'n deurslaggewende wyse as korrek te "bewys" nie, en daar bestaan eenvoudig nie 'n toereikende stel reëls in die lig waarvan besluit kan word of 'n nuwe benadering tot wetenskaplike probleme as 'n "paradigma" aanvaar moet word, of wanneer so 'n besluit geneem moet word nie. As 'n mens wetenskaplike rasionaliteit bloot beskou as 'n kwessie van die toepassing van objektief geldende reëls, soos in die geval van die klassieke rasionaliteitsmodel waarvan Brown sy "judgement model of rationality" onderskei (Brown, 1988:3-38), dan moet die keuse vir 'n paradigma as irrasioneel bestempel word ${ }^{12}$.

Die insig in die sentrale plek wat die uitoefening van gesonde oordeel in die praktyk van die akademie inneem, problematiseer in sonderheid die manier warop veral Hannah Arendt (1961) die skeiding van akademie en politiek by implikasie motiveer deur dit te probeer herlei na die verskille tussen die epistemologiese waarheidstrewe en opinievorming, en daarom na die vermeende verskille tussen kognisie en beoordeling. Arendt en andere wat die radikale skeibaarheid van akademie en politiek bepleit, misken die wesensbelangrike insigte wat spruit uit 'n post-empirisistiese wetenskapsfilosofie. Laasgenoemde toon onomwonde aan dat die uitoefening van gesonde oordeel tot sowel politiek as wetenskapsbeoefening behoort, en dat die beweerde onherleibare metodologiese verskille tussen die twee bestaansmodi in die verlede

\footnotetext{
11 Vir 'n kritiese bespreking van die toepaslikheid van sy "judgement model of rationality" vir die geesteswetenskappe vergelyk Van Niekerk (1990).

12 Selfs Kuhn is nie deurentyd gevrywaar van die suigkrag van dic klassicke rasionaliteitsmodel nie. Dit is dic enigstc verklaring vir die feit dat hy by gelecntheid dic aanvaarding van 'n paradigma as "arbitrêr" kan bestempel (Kuhn, 1970:4-5). Brown meen egter dat Kuhn, soos hyself, uiteindelik tot die gevolgtrekking kom dat die klassicke model van rasionaliteit venang moct word (Brown, 1988:112).
} 
oorbeklemtoon is. Die akademie ontdek danksy hierdie nuwere metodologiese analises van die wyse waarop wetenskap de facto beoefen word, dat akademie en wetenskap geen aanspraak kan maak op 'n suiwer intellektuele modus operandi wat onberoerd gelaat word deur die onsekerhede' en wisselvallighede van die historiese menslike bestaan, en deur die tipiese wyse waarop mense in alle bestaansfere op laasgenoemde reageer nie. As 'n slice of life is die wetenskap verwikkel en geïntegreer binne die totaliteit van die menslike lewe met al sy fasette - en dus ook met die uitoefening van keuses en die ontginning van strategieë wat tradisioneel sterker met die politieke lewe as die akademie geïdentifiseer is. Die akademiese bedryf van die wetenskap is geen geïsoleerde bedrywigheid sonder beïnvloeding deur en sonder invloed op hierdie ander fasette waarin die menslike lewe tot openbaring kom nie. Juis daarom maak dit nie net sin nie, maar word dit tewens vir 'n toereikende beeld van akademie en wetenskap vereis om opnuut te besin oor die verhouding waarin die wetenskap staan tot die volle spektrum van menslike bedrywighede. Hierdie bedrywighede sluit nie net die politiek in nie, maar ook aspekte soos arbeid en tegniek, kuns en etiek, lewensbeskouing en godsdienstige geloof.

\section{DIE POLTTIEKE VERANTWOORDELIKHEID VAN DIE UNIVERSITEIT}

Ons kom ten slotte by die vraag na hoe die verband tussen akademie en politiek verstaan moet word indien ons die pas bespreekte korreksies op die tradisionele dualisme in kultuur en filosofie afdoende wil verreken. Die eerste punt wat in hierdie verband gestel moet word is dat die aangeduide ontwikkelinge ons nie moet verlei om die onderskeid tussen akademie en politiek volledig oorboord te gooi nie. 'n Hele aantal van die analises wat ten grondslag lê van die dualisme van denkers wat in die eerste paragraaf bespreek is, het 'n sekere kwalik ontkenbare geldigheid. Die dualisme van akademie en politiek kan nie sonder meer prysgegee word ten gunste van 'n monisme wat alle terrein-, funksie- en benaderingonderskeidings tussen die twee bestaansmodi volledig wil ontken of nivelleer nie. Waar 'n sodanige monisme die geldige onderskeiding tussen akademie en politiek in die verlede oorwoeker het, was sowel die akademiese as politieke gevolge op hul beste onverkwiklik, en op hul slegste tragies.

Daar is veral twee gevare wat opdoem wanneer akademie en politiek sonder meer gelykgestel word. Die eerste is die verskynsel dat universiteite in so'n geval alte maklik gekaap word as legitimeerders van 'n bepaalde politieke ideologie, of dat politiek skaamteloos herlei word tot akademie. Dan word daar, soos Hannah Arendt tereg vrees, onder die dekmantel van "wetenskaplik demonstreerbare insigte", rasionalisasies 
aangebied vir die toepaslikheid van sommige van die mens se duisterste drifte en vooroordele, byvoorbeeld rassisme en kulturele chauvinisme. Arendt sou beweer dat die skyn van waarheid dan verleen word aan die mees twyfelagtige opinies. Ons is almal bewus van die wyse waarop so 'n misvormde bedryf van die akademie institusionele beslag gekry het oral waar die Stalinisme die kritiese afstand en onafhanklikheid van universiteite in (veral Oos-Europese) samelewings in die ban gedoen het. Ook die wyse waarop veral Afrikaanse universiteite in ons eie onlangse verlede hulle aan dergelike praktyke skuldig gemaak het, verteenwoordig een van die skandaligste hoofstukke in die geskiedenis van die Suid-Afrikaanse universiteitswese; 'n geskiedenis waaruit ons hopelik bereid is om te leer sodat dieselfde foute ten alle koste nie herhaal sal word in die toekoms, onder ander politieke heersers nie.

Die tweede gevaar is 'n situasie waar die teenoorgestelde plaasvind, dit wil sê waar wetenskap skaamteloos herlei of gereduseer word na politiek. Dit gebeur wanneer politieke maghebbers die eiesoortige (let wel: ek sê nie absolute nie!) gesag van wetenskaplik verworwe feite berekend geringskat en as niks anders as nog 'n reeks polities geïnspireerde, en daarom grondig bevooroordeelde opinies beskou en evalueer nie. Ook daarvan het ons 'n onverkwiklike ervaring aan eie lyf in die onlangse SuidAfrikaanse geskiedenis, veral gedurende die sewentigerjare, gehad. Die sewentigerjare was 'n periode toe veral sosiaal-wetenskaplikes, na die euforie van die sestigerjare toe die apartheidseksperiment miskien nog beskou kon word as 'n hipotese wat 'n kans gegun kon word, ondubbelsinnig begin wys het op die wyse waarop apartheid eenvoudig ontaard het in 'n dehumaniserende sosiale ingenieurswese wat geen ag slaan op skynbaar onkeerbare sosiale wetmatighede nie - wetmatighede soos verstedeliking en die ekonomiese vervlegtheid en interafhanklikheid van die hele bevolking van SuidAfrika. Wetenskaplik gefundeerde inligting van hierdie aard is tot en met die aanbreek van die tagtigerjare oorwegend deur die Suid-Afrikaanse politieke owerhede geïgnoreer, geringgeskat of as blote polities-geïnspireerde, "negatiewe" kwaadpraatjies bestempel. Die gevolg is dat ons vandag heroïes, en moontlik vrugteloos, moet probeer opmaak vir twee dekades se verlore geleenthede om in Suid-Afrika te kom tot 'n modus vivendi wat algemene aanvaarding geniet.

Die manier waarop hierdie ontsporings in die verhouding tussen akademie en politiek vermy kan word, is egter nie om die dualisme, soos voorgestel in die eerste paragraaf, intellektueel en prakties in ere te probeer herstel nie. Die ontwikkelinge wat in die tweede paragraaf bespreek is, ontmasker myns insiens so 'n gerehabiliteerde dualisme as 'n soft option in hierdie debat. Ons moet in die ontwikkeling van 'n eie visie op die probleem bemiddel tussen die onhoudbare dualisme van tradisionele beskouings, en 
die verideologiseerde monisme van meer eietydse pogings om akademie en politiek gelyk te probeer stel. Dit is my persoonlike standpunt dat onbedagte kompromieë oor die vryheid en outonomie van die (ook moderne) universiteit om self te besluit oor sy keuse van probleme, sy metodes van ondersoek en sy aanwending van bronne, die eiesoortige benadering tot probleemoplossings wat kenmerkend van akademiese wetenskapsbeoefening, en bygevolg die geheim van die suksesse van die moderne universiteit is, onvermydelik in die gedrang sal bring. So 'n standpunt hoef egter geensins te beteken dat die universiteit sy sosiale verantwoordelikheid as kultuurbemiddelaar binne 'n histories-institusionele, en dus ook politieke konteks, moet ontken nie. 'n Universiteit dank sy bestaan en verrig sy taak by die grasie van die openbare sanksie en ondersteuning van 'n samelewing wat baat vind by die akademiese bedryf. In hierdie sin van die woord kan dit nie ontken word dat ook die moderne universiteit in 'n heel besondere sin 'n "politieke verantwoordelikheid" het nie. Wat hierdie verantwoordelikheid is, moet egter goed verstaan word.

Ek maak ten slotte net enkele opmerkings oor hierdie verantwoordelikheid.

* Hierdie verantwoordelikheid is in die eerste plek diensbaarheid, sonder om dienstig te wees. Daar is niks mee verkeerd dat 'n universiteit in sy navorsings- en onderrigprogramme inspeel op die behoeftes van sy politiek-institusionele omgewing nie, solank sy vryheid om tot bevindinge te geraak wat eksklusief berus op wetenskaplik oorwoë en geëvalueerde getuienis, op geen manier in die gedrang kom of gekompromitteer word nie. 'n Samelewing, en met name die politieke owerhede van 'n samelewing wat van die dienste van die universiteit gebruik maak, moet bereid wees om te hoor presies waar Dawid die wortels gegrawe het. Die universiteit is aan niemand verskonings verskuldig vir die feit dat die waarheid, wat sy enigste norm vir ondersoek is, soms seermaak nie.

* Die universiteit se sosiaal-politieke verantwoordelikheid is in die tweede plek verkenning sonder voorskriftelikheid. Sy akademiese vryheid en outonomie stel die universiteit nie slegs in staat nie, maar lê ook op hom die plig om verkennend en eksperimenteel te werk te gaan ten opsigte van onopgeloste probleme in die samelewing. As die samelewing beskou kan word as 'n ossewa wat stadig beweeg en nie maklik gedraai word nie, kan die universiteit bestempel word as die touleier. Die touleier is nie die baas wat die sweep klap, op die wakis sit en besluit waarheen die reis gaan nie. Die touleier moet egter bepaal of die roete wat tans gevolg word, begaanbaar is; hy moet uitkyk vir dorings en dongas, hy moet soms nuwe paaie na die bestemming prakseer. Die touleier verken, want hy sien die pad voor die baas en die osse dit sien. So ook in die verhouding tussen universiteit en same- 
lewing: die universiteit besluit nie wat 'n samelewing se bestemming is nie; die universiteit regeer nie die land nie, en al droom mense sedert Plato se dae van filosowe wat konings is, kan ons dankbaar wees dat dit meesal nog net 'n droom gebly het. Maar die universiteit moet egter verken of die ingeslane weg begaanbaar is en of die bestemming bereikbaar is sonder voetseer osse en 'n vasgevalde wa.

- Die derde en laaste sosiaal-politieke verantwoordelikheid van die universiteit wat ek wil onderskei, is waardebemiddeling sonder indoktrinasie. Waarskynlik die belangrikste diens wat 'n universiteit aan sy samelewing kan lewer, is wanneer hy sy sosiale verbondenhede gebruik as 'n kanaal waardeur hy sy eie akademiese waardes vaardig kan maak in die kulturele lewe van die gemeenskap waarmee hy hom vereenselwig en waarin hy sy onderrigtaak verrig ${ }^{13}$.

Die universiteit dien die samelewing nie ten beste as hy sy onderwystaak sien as die selfvoldane beskikbaarstelling van feite en informasie, van oplossings en kategoriese voorskrifte nie, want die universiteit, soos ons vroeër gesien het, is maar alte bewus van hoe voorlopig en tentatief, pending further evidence, ook sy netjiesste en op die oog af indrukwekkendste navorsingsresultate is. Om resultate aan te bied as die finale waarheid, sou neerkom op indoktrinasie, dit is die opdwing van "feite" en "inligting" wat nie die toets van kritiese uitsuiwering kon deurstaan nie. Die universiteit dien die samelewing veel beter as hy sy onderwystaak eerder sien as 'n geleentheid om by te dra tot die vestiging en institusionalisering van wat ek, by gebrek aan 'n beter woord, 'n wetenskaplike mentaliteit in die aanpak en bearbeiding van vraagstukke op alle terreine van die gemeenskapslewe wil noem. Soos wat die wetenskap die prevalensie van allerlei "nie-akademiese" invloede op sy eie praktyk en bedryf moet erken, so kan die samelewing inderdaad heelwat baat vind by die deursuring van 'n akademies-wetenskaplike manier van doen. Die universiteit het die taak om in sy onderrig- en gemeenskapsdiensprogramme alles in werking te stel om die samelewing nie soseer te voorsien van mense wat ensiklopedies meer feite en tegnieke as vroeër paraat het nie, maar wat die waardes wat ten grondslag lê van wetenskapsbeoefening en wetenskaplike denke, vaardig maak in die algemene manier waarop die samelewing se probleme benader word. Ek bedoel hiermee waardes soos dié van rasionaliteit en objektiwiteit, van verdraagsaamheid en die oop gesprek, van onafhanklike ondersoek en die eerlike oorweging van alle beskikbare getuienismateriaal, van kritiese denke en die openheid vir alternatiewe standpunte, van gegronde oordeelsvorming en die gewilligheid om jou idees deur ander te laat kontroleer.

\footnotetext{
${ }^{13}$ Ek maak in die beredenering van hierdie punt heclwat gebruik van dic insigtc van Rossouw (1987:8-9).
} 
Die besondere belang van hierdie akademiese waardes is dat hulle kommunikasie oor alle grense heen moontlik maak en promoveer. Hulle is waardes wat ons help om natuurlike en mensgemaakte verdelings te transendeer en die grondslag te lê vir dialoog en die soeke na onderlinge konsensus en begrip. Die strewe na akademiese waardes van hierdie aard kan 'n onmisbare bydrae lewer om die andersheid en die onderlinge vreemdheid wat individue en groepe van en aan mekaar ervaar, te omskep vanaf ' $n$ bron van onsekerheid en bedreiging, tot ' $n$ bron van verryking en verruiming. Die universiteit as instelling wat sulke waardes in die praktyk bring en in die samelewing vaardig maak, kan 'n wesenlike bydrae lewer om vervreemding deur kommunikasie te oorwin. Langs dié weg is dit nie alleen moontlik om die konflikpotensiaal van ons diepverdeelde samelewing te help ontlont nie, maar om ook 'n meer inklusiewe en 'n meer universele ervaring en ekspressie van menslikheid te bevorder.

Die universiteit het daarby die verantwoordelikheid om nie alleen die tradisionele waardes van die akademiese gesprek onvervals oor te dra nie, maar om ook in die praktyk van die universitêre gemeenskapslewe as 'n voorbeeld vir die samelewing te dien, dit is om te demonstreer hoe konsensus deur kommunikasie bereik kan word ${ }^{14}$. 'n Universiteit wat dáárin slaag, word deur die waardes wat hy vaardig maak en demonstreer, self een van die belangrikste waardes in 'n beskaafde samelewing, want dan slaag hy daarin om iets toe te voeg tot die twee klassieke ideale wat tot nou toe deur universitêre kennisverwerwing nagestreef is, en waarna vroeër verwys is, naamlik die bevordering van deug en die verwerwing van mag. In ons tyd, en veral in Afrika, is ons behoeftes nie net deug en mag nie, maar ook bevryding of emansipasie. 'n Universiteit wat daarin slaag om die waardes wat hom identifiseer vaardig te maak in die kultuur waarin hy werk, maak van akademies-wetenskaplike kennisverwerwing 'n proses wat nie net deugsame en magtige mense en instellings produseer nie, maar wat instrumenteel is in die psigologiese, intellektuele en politieke bevryding van die slagoffers van eeue van onreg.

\footnotetext{
${ }^{14} \mathrm{Jürgen} \mathrm{Habermas} \mathrm{(1970:1-12)} \mathrm{wys} \mathrm{in} \mathrm{'n} \mathrm{opstel} \mathrm{oor} \mathrm{die} \mathrm{demokratisering} \mathrm{van} \mathrm{die} \mathrm{universiteit} \mathrm{op}$ dic verband wat daar bestaan tussen 'n demokratiese vorm van politieke besluitneming, en die soort diskussie waaraan die wetenskappe hul vordering te danke het. Veral op die vlak van metateoretiese (of wetenskapsmetodologiese) besinning, is daar 'n ooreenkoms tussen die beslegting van kwessies wat vra om 'n rasionalisasie van keuse in dic medium van onbelemmerde diskussic, en demokratiesc interaksic. Anders as Minogue, wat vrocër bespreck is, pla dit Habermas nic baic dat beshitneming in dic politiek, anders as in dic akademic, van kardinale belang is nic. Die verskil tussen akademic en politick in hicrdic sin is slegs dat besluite deur die meerderheid in die politick soms geneem moet word vir praktiese redes, terwyl die gesprek self, soos in dic akademic, in beginsel voortgesit sou kon word totdat konsensus bercik word.
} 


\section{BIBLIOGRAFIE}

ARENDT, H. 1961. Between past and future. New York: The Viking Press

ALTHUSSER, L. 1972. Ideology and ideological state aparatuses. ( $/$ il Cosin, B.R. ed. Education: structure and society. Harmondsworth : Penguin, pp. 242-280.)

BERNSTEIN, R.J. 1986. Philosophical prophites. Cambridge : Polity Press.

BROWN, H.I. 1988. Rationality. London : Routledge.

DOYAL, L. \& HARRIS, R. 1986. Empiricism, explanation and rationality. London : Routledge \& Kegan Paul

FoUCAULT, M. 1980. Power/Knowledge. Brighton : The Harvester Press.

HABERMAS, J. 1970. Toward a rational socicty. Boston : Beacon Press.

JASPERS, K. 1960 . The idea of the university. London : Peter Owen.

KUHN, T.S. 1962. The structure of scientific revolutions (Second enlarged edition). Chicago : The Universily of Chicago Press.

KUIN, T.S. 1970. Logic of discovery or psychology of research? (In Lakatos, I. \& Musgrave, A Criticism and the growth of knowledge. Cambridge : Cambridge University Press, pp. 1-23.)

LAKATOS, 1. 1970). Falsification and the methodology of scientific research programmes ( $/$ h Lakatos, I \& Musgrave, A. Criticism and the growth of knowledge. Cambridge : Cambridge University Press, pp. 91-195.)

MARIN, L. 1975. "Le Neutre" and philosophical discourse. (In Montefiore, A.ed. Neutrality and impartiality. London: Cambridge University Press. p. 86-127.)

MARX, K. \& EN(jELS, F. 1970. The German ideology (C. Arthur ed.). London : Lawrence \& Wishart.

MINOGUE, K.R. 1973. The concept of a university. London: Weidenfeld and Nicolson.

MOBERLY, W.H. 1949. The crisis in the university. London : S.C.M. Press.

MOULDER, J. 1977. University neutrality : some puzzling reflections in a South African mirror. (In Van der Merwe, H.W. \& Welsh, D. eds. The future of the university in South Africa. Cape Town : David Philip, pp. 245-25\%.)

MUSGRAVE, P.W. 1973. The sociology of education. London : Methuen

RORTY, R. 1985. Solidarity or objectivity? (In Rajchman, J. \& West, C. eds. Post-analytic philosophy. New York : Columbia University Press, pp. 3-19.)

ROSSOUW, H.W. 1980. Wetenskap, interpretasie, wysheid. Port Elizabeth : Universitcil van Port Elizabcth seminare, simposiums en lesings B7.

ROSSOUW, H.W. 1986. Oor wetenskapskulture en die idee van dic universiteit. (In Du Toit, A.B. In gesprck. Opstelle vir Johan Degenaar. Kaapstad : Dic Suid-Afrikatan, pp. 55-60.)

ROSSOUW, H.W. 1987. Uitdagings aan dic universitêre onderwys (A.J. Brink (jelecntheidslesing) Stcilenhosch : Universiteit van Stellenbosch.

SEARLE, J. 1971. The campus war. Harmondsworth : Penguin Books.

SIMON, R.L. 1972. The concept of a politically neutral university. ( $h$ Held, V. et al. eds. Philosophy and political action. London: Oxford University Press.

TOULMIN, S. 1961. Foresight and understanding: an enquiry into the aims of science. London : Hutchinson.

VAN NIEKERK, A.A. 1987. Dic begrip ideologic : geskiedenis en konseptuele analise. (In Esterhuyse, W.P. et al reds. Moderne politicke ideologiec̈. Johannesburg : Southern Books, pp.3-36.)

VAN NIEKERK, A.A. 1990 . To follow a rule or to rulc what should follow? Rationality and judgement in the human sciences. (In Mouton, J. \& Joubert, D.D. Knowledge and method in the human sciences. Pretoria : Human Sciences Rescarch Council, pp.179-194.)

WEBER, M. 1973. Max Weber on universities (tr. E. Shils). Chicago: The University of (hicago Press. 